\title{
GLOSA DO WYROKU SN Z DNIA 21 SIERPNIA 2019 ROKU, I CSK 349/181 — UWAGI O KONIECZNOŚCI DORĘCZENIA OŚWIADCZENIA WOLI ADRESATOWI W WYMAGANEJ FORMIE SZCZEGÓLNEJ
}

\begin{abstract}
Abstrakt: Przedmiotem glosy jest wyrok SN z dnia 21 sierpnia 2019 roku, I CSK 349/18, w którym wypowiedziany został pogląd, zgodnie z którym ,jeżeli pod rygorem nieważności wymaga się, w stosunku do określonego oświadczenia woli składanego innej osobie, zachowania formy szczególnej w postaci pisma, to dla przyjęcia, że zostało ono złożone i wywołało skutki prawne konieczne jest doręczenie adresatowi oryginału pisma zawierającego to oświadczenie woli”. Mimo że zdanie to wpisuje się w stanowisko, które dominuje zarówno w judykaturze, jak i w piśmiennictwie, autorka glosy zwraca uwagę na potrzebę weryfikacji argumentów, jakie doprowadziły do jego ukształtowania. W tym celu analizuje motywy wskazane w uzasadnieniu wyroku, w tym również przywołane w nim stanowisko SN wyrażone w uchwale z dnia 20 lutego 1967 roku, III CZP 88/66. Ostatecznie dochodzi do wniosku, że kategoryczność glosowanej tezy jest nieuzasadniona. Przemawia za tym nie tylko brak konkretnego przepisu, z którego wynikałby obowiązek doręczenia adresatowi oświadczenia woli w takiej formie, jaka pod rygorem nieważności jest wymagana do jego złożenia, ale również wzgląd na wykładnię funkcjonalną przepisów o składaniu oświadczeń woli. Autorka zwraca uwagę, że kopia pisma obejmującego oświadczenie woli zabezpiecza w pełni interes adresata wyrażający się w możliwości pełnego zaznajomienia się z faktem złożenia tego oświadczenia i jego treścią.
\end{abstract}

Słowa kluczowe: forma pisemna, dokument, kopia, oryginał dokumentu, złożenie oświadczenia woli innej osobie, forma szczególna

\section{WPROWADZENIE}

W wyroku z dnia 21 sierpnia 2019 roku Sąd Najwyższy sformułował tezę, zgodnie z którą

jeżeli pod rygorem nieważności wymaga się, w stosunku do określonego oświadczenia woli składanego innej osobie, zachowania formy szczególnej w postaci pisma, to dla przyjęcia, że zostało

1 Wyrok SN z dnia 21 sierpnia 2019 roku, I CSK 349/18. 
ono złożone i wywołało skutki prawne konieczne jest doręczenie adresatowi oryginału pisma zawierającego to oświadczenie woli.

Pogląd został wyrażony na tle sprawy dotyczącej żądania gwarancji bankowej realizacji świadczenia pieniężnego z udzielonej beneficjentowi gwarancji. Jako że zgodnie z art. 81 ust. 2 Prawa bankowego ,udzielenie i potwierdzenie gwarancji bankowej następuje na piśmie pod rygorem nieważności”"2, Sąd Najwyższy doszedł do wniosku, że doręczenie beneficjentowi zamiast oryginału gwarancji, skanu oświadczenia banku o przedłużeniu okresu gwarancji na kolejny, jest równoznaczne z tym, że na podstawie art. 81 ust. 2 Prawa bankowego w zw. z art. 73 $\S 1 \mathrm{KC} \mathrm{w} \mathrm{zw.} \mathrm{z} \mathrm{art.} 77 \S 1 \mathrm{KC}$ oraz art. 60 i $61 \mathrm{KC} \mathrm{w} \mathrm{zw.} \mathrm{z} \mathrm{art.} 81$ ust. 2 Prawa bankowego nie doszło do złożenia takiego oświadczenia, a w konsekwencji że gwarancja nie została przedłużona ${ }^{3}$.

Sposób sformułowania glosowanej tezy sugeruje jej uniwersalny charakter, nie sprowadzający zastosowania wyrażonego w niej poglądu wyłącznie do czynności polegającej na przedłużeniu okresu gwarancji bankowej ${ }^{4}$. Trzeba też odnotować, że zdanie Sądu Najwyższego wpisuje się w linię orzeczniczą ukształtowaną już wcześniej w innych sprawach ${ }^{5}$. W tym samym czasie, mimo że pogląd o konieczności doręczenia adresatowi oświadczenia woli w formie wymaganej dla ważności tego oświadczenia wydaje się dominować również w piśmiennictwie ${ }^{6}$, nie jest on poglądem niekwestionowanym ${ }^{7}$. Konfrontacja stanowisk wyrażanych w tej kwestii nie stanowi podstawowego powodu, dla którego warto poddać analizie wska-

2 Ustawa z dnia 29 sierpnia 1997 roku — Prawo bankowe, Dz.U. z 2020 r. poz. 1896 ze zm.

3 Pogląd wyrażony w wyżej opisanym wyroku SN podtrzymał także Sąd Apelacyjny w Warszawie w wyroku z dnia 28 listopada 2019 roku, VII Aga 716/19, ponownie rozpoznając sprawę w następstwie wyroku SN z dnia 21 sierpnia 2019 roku.

4 Z tego względu w analizie zostaną wyeksponowane wątki dotyczące skuteczności składania oświadczenia woli w kontekście istniejących wymogów formalnych z pominięciem szczegółowych kwestii dotyczących gwarancji bankowej.

5 Por. wyrok SN z dnia 21 czerwca 1965 roku, III PR 18/65, „Nowe Prawo” 1966, nr 4; uzasadnienie uchwały SN (7) — zasada prawna z dnia 20 lutego 1967 roku, III CZP 88/66, OSNCP 1967, nr 12, poz. 210; uzasadnienie uchwały SN (7) z dnia 31 marca 2016 roku, III CZP 89/15; wyrok SA w Krakowie z 27 czerwca 2013 roku, I ACa 542/13; wyrok SA w Białymstoku z dnia 4 kwietnia 2010 roku, I ACa 83/08.

${ }^{6}$ M. Safjan, Uwagi do art. 61 k.c., Nb 10, [w:] Kodeks cywilny, t. 1. Komentarz. Art. 1-44910, red. K. Pietrzykowski, Warszawa 2020; P. Machnikowski, Kodeks cywilny. Komentarz, red. E. Gniewek, P. Machnikowski, Warszawa 2019, s. 145; K. Mularski, Z. Radwański, [w:] Prawo cywilne - część ogólna. System Prawa Prywatnego, t. 2, Warszawa 2019, s. 374; J. Grykiel, Uwagi do art. 61 k.c., $\mathrm{Nb}$ 35, [w:] Kodeks cywilny, t. 1. Komentarz do art. 1-352, red. M. Gutowski, Warszawa 2018; M. Giaro, Glosa do wyroku SN z 26.08.2009 r., I CSK 32/09, „Państwo i Prawo” 2011, nr 1, s. 119-120; M. Słomko, Złożenie oświadczenia woli w formie aktu notarialnego, „Przegląd Sądowy" 2005, nr 3.

7 Zob. wyrok SN z 30 maja 2000 roku, IV CKN 898/00, OSNC 2000 nr 12, poz. 224, str. 53 z glosą krytyczną B. Janiszewskiej, „Przegląd Sądowy” 2002, nr 1; wyrok SN z 26 sierpnia 2009 roku, I CSK 32/09; wyrok SA w Warszawie z 20 stycznia 2015 roku, VI ACa 200/14. W piśmiennictwie zaś zob. stanowisko M. Piekarskiego, Glosa do wyroku SN z dnia 21.06.1965 roku, III PR 
zane stanowisko SN. Przemawiają za tym szczególne okoliczności sprawy, które wobec finalnego rozstrzygnięcia SN prowokują pytanie, czy w analizowanym wypadku daleko idący formalizm w odniesieniu do sposobu składania oświadczeń woli innej osobie przysłużył się realizacji typowych celów wyznaczanych w związku z wymogami formalnymi (choćby bezpieczeństwo obrotu). W świetle analizowanego orzeczenia SN pojawia się również inny kontekst. Nie sposób zignorować występującej współcześnie na wielu różnych poziomach tendencji do odformalizowywania obrotu prawnego. Dokonywanie czynności prawnych przy użyciu coraz to bardziej nowoczesnych środków komunikacji elektronicznej jest faktem. Skanowanie dokumentów papierowych, robienie ich fotokopii, wiadomości głosowe są częstym sposobem przekazywania informacji. W związku z wprowadzeniem do kodeksu cywilnego szerokiej definicji dokumentu, uwzględniającej również jego elektroniczną (niematerialną) postać ${ }^{8}$, osłabła konieczność dysponowania przez zainteresowany podmiot tradycyjną wersją dokumentu. O ile tylko dokument obejmuje tekst i umożliwia ustalenie jego wystawcy, sąd stosuje do niego przepisy o dowodzie $\mathrm{z}$ dokumentów ${ }^{9}$. Dowód z pozostałych dokumentów sąd przeprowadza, stosując odpowiednio przepisy o dowodzie z oględzin oraz o dowodzie z dokumentów ${ }^{10}$. W obrocie cywilnoprawnym powszechnie dopuszcza się również możliwość użycia kopii dokumentu, która posiada wartość dowodową w postępowaniu sądowym ${ }^{11}$. Zwraca się przy tym uwagę, że stosowanie kopii może zostać wyłączone wolą samych stron albo ze względu na funkcje, którym konkretny dokument ma służyć ${ }^{12}$. Wszystkie te okoliczności nie pozostają bez znaczenia, gdy chodzi o ocenę sposobu komunikowania drugiej stronie faktu złożenia oświadczenia woli. Wobec braku jednoznacznego przepisu określającego formę, w jakiej powinno zostać doręczone adresatowi oświadczenie woli, podstawowe znaczenie w tej kwestii ma wykładnia celowościowa art. $61 \mathrm{KC}$. W tym kontekście aktualizuje się pytanie o potrzebę i ewentualny zakres formalizowania sposobu komunikowania adresatowi woli wywołania skutków prawnych.

18/65, „Nowe Prawo” 1966, nr 4; por. też P. Sobolewski, Komentarz do art. 61 KC, pkt. 18, [w:] Kodeks cywilny. Komentarz, red. K. Osajda, Warszawa 2021.

8 Zgodnie z art. $77^{3} \mathrm{KC}$ „dokumentem jest nośnik informacji umożliwiający zapoznanie się z jej treścią". Normatywna definicja dokumentu została wprowadzona ustawą z 10 lipca 2015 roku o zmianie ustawy — Kodeks cywilny, ustawy — Kodeks postępowania cywilnego oraz niektórych innych ustaw (Dz.U. z 2015 r. poz. 1311) obowiązującą od dnia 8 września 2016 roku.

${ }^{9}$ Zob. art. $243^{1} \mathrm{KPC}$.

10 Zob. art. $308 \mathrm{KPC}$.

11 Zob. między innymi postanowienie SN z 12 lutego 2019 roku, II PK 12/18.

$12 \mathrm{Na}$ ten temat zob. K. Górska, Pojęcie dokumentu w prawie cywilnym - głos $w$ dyskusji nad istota regulacji art. $77^{3} \mathrm{KC}$, „Przegląd Ustawodawstwa Gospodarczego” 2021, nr 5, s. 59 i cytowana tam literatura. 


\section{ZARYS STANU FAKTYCZNEGO}

Podstawą orzeczenia SN był następujący stan faktyczny: 14 lipca 2011 roku została zawarta umowa o roboty budowlane pomiędzy C. jako inwestorem a B. jako wykonawcą, na podstawie której wykonawca B. zobowiązał się do przedłożenia inwestorowi C. bankowej gwarancji należytego wykonania robót budowlanych ważnej aż do dnia, który nastąpi po upływie piętnastu dni od wydania wykonawcy protokołu odbioru końcowego zakresu prac bez zastrzeżeń. W dniu 1 września 2011 roku Bank, działając na zlecenie B., wystawił na rzecz C. - beneficjenta gwarancji - pisemną rękojmię wykonania opisanej umowy, w której bezwarunkowo i nieodwołalnie zobowiązał się wobec C. do zapłaty sumy gwarancyjnej do kwoty 1750000 zł na pierwsze żądanie skierowane do Banku w sposób szczegółowo opisany w tym dokumencie. Zawarto w nim także zapis, że z chwilą zwrotu Bankowi oryginału gwarancji, odpowiedzialność Banku ustaje nawet przed upływem terminu ważności, jaki wynika z gwarancji. Gwarancja wystawiona 1 września 2011 roku była ważna do 31 marca 2012 roku; oryginał dokumentu gwarancji został przekazany C. osobiście przez przedstawiciela B. W dniu 20 marca 2012 roku Bank na zlecenie B. przedłużył okres ważności udzielonej gwarancji do 30 czerwca 2012 roku. Oryginał dokumentu zmiany nr 1 do gwarancji został doręczony powodowi drogą pocztową. W związku z przedłużającą się realizacją umowy B. wezwał C. do przedstawienia gwarancji zapłaty za roboty budowlane na kwotę 5191521 zł. C. odmówił ustanowienia gwarancji w żądanej wysokości; między stronami toczyły się następnie rozmowy dotyczące tej kwestii

W dniu 29 czerwca 2012 roku w siedzibie Banku stawił się przedstawiciel B., który miał odebrać wcześniej przygotowany przez Bank na zlecenie B. dokument zmiany $\mathrm{nr} 2$ do gwarancji bankowej, polegającej na przedłużeniu okresu jej ważności do 31 grudnia 2012 roku. Przedstawiciel B. poprosił pracownika Banku o zeskanowanie tego dokumentu i przesłanie mu skanu pocztą elektroniczną na jego skrzynkę. Następnie przedstawiciel B. przesłał skan tego dokumentu pocztą elektroniczną do pracownika C., po czym skontaktował się z nim telefonicznie w celu ustalenia, czy C. dysponuje gwarancją bankową zapłaty wynagrodzenia za wykonane przez B. roboty budowlane. Po uzyskaniu odpowiedzi przeczącej, nadal przebywający w siedzibie Banku przedstawiciel B. oświadczył pracownikowi Banku, że B. rezygnuje z wystawienia zmiany $\mathrm{nr} 2$ do gwarancji bankowej i zwrócił mu oryginał dokumentu zawierającego zmianę nr 2 do gwarancji. W tej sytuacji przedstawiciele Banku nanieśli na ten dokument adnotację o anulowaniu gwarancji, pod którą osoby te złożyły własnoręczne podpisy. Oryginał dokumentu zmiany $\mathrm{nr} 2$ do gwarancji nigdy nie opuścił siedziby Banku. Pismem z dnia 29 czerwca 2012 roku, doręczonym C. 2 lipca 2012 roku, B. złożył oświadczenie o odstąpieniu od umowy o roboty budowlane ze względu na nieprzedłożenie przez inwestora gwarancji zapłaty wynagrodzenia za wykonane prace. W piśmie z 4 lipca 2012 roku C. uznał to odstąpienie od umowy za bezskuteczne, zaś w kolejnym piśmie 
z 5 lipca 2012 roku skierowanym do B. dokonał wypowiedzenia umowy o roboty budowlane, powołując się na ich niewykonanie przez kontrahenta. Równolegle 5 lipca 2012 roku C. wystąpił do Banku z żądaniem wypłaty kwoty 1750000 zł, oświadczając, że B. nienależycie wykonał zobowiązanie z umowy. Pismem z dnia 20 lipca 2012 roku Bank poinformował C., że odmawia wypłaty żądanej kwoty z gwarancji ze względu na to, że okres jej ważności zakończył się 30 czerwca 2012 roku, zaś przed jej wygaśnięciem Bank nie złożył powodowi oświadczenia woli w formie pisemnej pod rygorem nieważności o udzieleniu kolejnej gwarancji lub wydłużeniu terminu dotychczasowej gwarancji. W tej sytuacji C. pozwał Bank o zapłatę kwoty $175000 \mathrm{zł}$ tytułem realizacji gwarancji bankowej wystawionej na rzecz powoda $\mathrm{C}$. przez pozwany Bank na zlecenie B. występującego w charakterze interwenienta ubocznego po stronie pozwanego Banku. Sąd I instancji oddalił powództwo jako niezasadne, podzielając argumentację pozwanego i interwenienta, że nie doszło do skutecznego przedłużenia gwarancji bankowej na rzecz powoda po upływie okresu jej ważności wynikającego ze zmiany nr 1 (to jest po 30 czerwca 2012 roku). Z kolei Sąd Apelacyjny w Warszawie jako sąd II instancji zmienił zaskarżony wyrok na skutek apelacji w ten sposób, że zasądził od pozwanego Banku na rzecz powoda C. kwotę dochodzoną pozwem. Sąd Apelacyjny podzielił ustalenia faktyczne sądu I instancji, ale dokonał ich odmiennej oceny prawnej, dochodząc do wniosku, że doszło do skutecznego przedłużenia gwarancji. Sąd Apelacyjny uzasadnił to zwłaszcza w ten sposób, że między powodem C. i pozwanym Bankiem oraz spółką B. doszło do ukształtowania praktyki polegającej na tym, że najpierw przesłano powodowi C. pocztą elektroniczną skan dokumentu gwarancji z 1 września 2011 roku i skan dokumentu obejmującego zmianę $\mathrm{nr} 1$ do gwarancji, a następnie powód otrzymał te dokumenty w oryginale. Wobec tego przesłanie powodowi C. przez przedstawiciela B. 29 czerwca 2012 roku pocztą elektroniczną skanu dokumentu zmiany $\mathrm{nr} 2$ do gwarancji spowodowało, że powód miał prawo pozostawać w uzasadnionym przekonaniu, że Bank złożył ważne i skuteczne oświadczenie woli o przedłużeniu gwarancji bankowej do 31 grudnia $2012 \mathrm{roku}^{13}$.

\section{KLUCZOWE PROBLEMY PRAWNE}

Jak słusznie wskazał Sąd Najwyższy, ,przedmiotem i istotą sporu było w tej sprawie przede wszystkim to, czy doszło do przedłużenia okresu ważności gwarancji bankowej udzielonej na rzecz powoda w dniu 1 września 2011 roku, na dalszy okres (do dnia 31 grudnia 2012 roku) po upływie — z dniem 30 czerwca 2012 roku — okresu jej ważności”. Tak zarysowany problem implikuje konieczność

13 Opis stanu faktycznego na podstawie uzasadnienia wyroku SN z dnia 21 sierpnia 2019 roku. 
dokonania oceny, czy doszło do złożenia oświadczenia o przedłużeniu gwarancji, czy oświadczenie to było ważne oraz, czy było ono skuteczne. W kontekście okoliczności faktycznych sprawy oznacza to potrzebę dokonania analizy w kilku obszarach: po pierwsze, jakie znaczenie miało sporządzenie 29 czerwca 2012 roku przez Bank dokumentu obejmującego udzielenie gwarancji na rzecz C., w szczególności zaś czy takiej czynności można przypisać walor oświadczenia woli; po drugie, czy oświadczenie Banku o przedłużeniu gwarancji można uznać za złożenie beneficjentowi gwarancji w rozumieniu art. $61 \mathrm{KC}$; i po trzecie, jaki charakter prawny należy przypisać ,,anulowaniu gwarancji” dokonanemu przez Bank i zleceniodawcę gwarancji oraz czy wywołało ono skutki wobec beneficjenta tej ostatniej.

\section{ARGUMENTACJA SĄDU NAJWYŻSZEGO}

Zważywszy na wielowarstwowy aspekt zagadnienia prawnego, jakie pojawiło się na tle analizowanej sprawy, uzasadnienie wyroku Sądu Najwyższego wydaje się dość lakoniczne - jego ocena prawna sprowadziła się wyłącznie do ustalenia tego, czy oświadczenie Banku można uznać za złożone beneficjentowi gwarancji w rozumieniu art. $61 \mathrm{KC}^{14}$. W tym zakresie Sąd Najwyższy ograniczył się do odesłania do poglądów wyrażanych wcześniej w judykaturze. Z przywołanych przez SN orzeczeń istotna jest uchwała SN w składzie siedmiu sędziów — zasada prawna z dnia 20 lutego 1967 roku — w uzasadnieniu której znalazło się zdanie, że „W wypadku, gdy oświadczenie woli ma być złożone w odpowiedniej formie, powinno ono dojść do osoby, do której jest skierowane, w takiej właśnie postaci”15.

$\mathrm{W}$ warstwie argumentacyjnej uzasadnienia SN zwrócił również uwagę, że jakakolwiek praktyka ustalona między stronami dotycząca sposobu doręczania oświadczeń woli nie może być sprzeczna z przepisami bezwzględnie obowiązującymi. SN nie wskazał przy tym, z jakim konkretnie przepisem pozostawała w sprzeczności praktyka dotycząca składania oświadczeń woli. W to miejsce posłużył się ogólnym stwierdzeniem, że do takich (to jest bezwzględnie wiążących) należą , przytoczone wyżej regulacje”, a więc — jak należy rozumieć — wskazane w uzasadnieniu glosowanego orzeczenia przepisy ,art. 81 ust. 2 PrBank w zw. z art. $73 \S 1 \mathrm{KC} \mathrm{w}$ zw. z art. $77 \S 1 \mathrm{KC}$ oraz art. $60 \mathrm{i} 61 \mathrm{KC} \mathrm{w} \mathrm{zw.} \mathrm{z} \mathrm{art.} 81$ ust. 2 PrBank". Ponadto SN wskazał, że nawet jeśli taka praktyka była ustalona, to obejmowała ona również każdorazowo doręczanie oryginału oświadczenia Banku beneficjentowi gwarancji, co jednak nie miało miejsca w odniesieniu do spornego oświadczenia obejmującego przedłużenie okresu gwarancji na okres do 31 grudnia

14 Determinuje to również zakres rozważań podjętych w ramach glosy.

15 III CZP 88/66, OSNCP $1967 \mathrm{nr}$ 12, poz. 210. Pozostałe dwa orzeczenia przywołane w wyroku SN (to jest uchwała SN [7] z dnia 31 marca 2016 roku, III CZP 89/15, OSNC 2016, nr 9, poz. 97 oraz wyrok SN z dnia 17 czerwca 2009 roku, IV CSK 53/09) podzielają stanowisko SN wyrażone w uchwale z 20 lutego 1967 roku, jednak nie zawierają dodatkowej argumentacji dla jego poparcia. 
2012 roku. Zdaniem SN dopiero w chwili doręczenia beneficjentowi gwarancji oryginałów oświadczeń Banku powstały skutki prawne z nimi związane, o czym jak podkreślił SN — ,powód jako profesjonalny uczestnik obrotu gospodarczego, dysponujący fachową obsługą prawną, powinien wiedzieć”.

\section{OCENA STANOWISKA SĄDU NAJWYŻSZEGO}

Jak wcześniej wskazano, pogląd o konieczności doręczenia adresatowi oświadczenia woli w takiej formie, jaka pod rygorem nieważności jest przewidziana dla jego złożenia, zdecydowanie dominuje zarówno w judykaturze, jak i w piśmiennictwie ${ }^{16}$. Być może z tego właśnie względu uzasadnienie tezy SN zawartej w wyroku z dnia 21 sierpnia 2019 roku ma charakter w znacznym stopniu ramowy, odsyłający do stanowiska wyrażanego we wcześniejszym orzecznictwie. Taki sposób uargumentowania oceny prawnej dokonanej przez SN w świetle okoliczności faktycznych analizowanej sprawy należy jednak uznać za niewystarczający.

Przede wszystkim, pomimo supremacji poglądu przenoszącego wymóg co do formy złożenia oświadczenia woli na wymóg doręczenia w tej samej formie oświadczenia jego adresatowi, trzeba zwrócić uwagę na to, że nie jest to pogląd oparty na gramatycznej wykładni art. $61 \mathrm{KC}$. Tymczasem można odnieść wrażenie, że jego ugruntowanie w judykaturze i doktrynie nastąpiło siłą pewnego rodzaju inercji. Stosunkowo rzadko bowiem można się spotkać z próbą przedstawienia jakiejkolwiek argumentacji dla jego poparcia. W tych przypadkach, w których dochodzi do uzasadnienia analizowanej tezy, wskazuje się najczęściej na takie okoliczności, jak: zapewnienie bezpieczeństwa obrotu postrzeganego - co warto podkreślić — z perspektywy ochrony sytuacji adresata oświadczenia woli ${ }^{17}$, zapewnienie możliwości dysponowania dokumentem przez adresata ${ }^{18}$ czy na potrzebę realizacji typowych funkcji związanych z formą czynności prawnych ${ }^{19}$.

Ponadto odesłanie przez SN do wcześniejszych orzeczeń nastąpiło przy całkowitym pominięciu motywów, jakie legły u podstaw takich, a nie innych ocen prawnych. Te zaś wydają się być niepozbawione znaczenia, ponieważ stawiają analizowaną $\mathrm{w}$ tej glosie tezę $\mathrm{w}$ nieco innym świetle.

Z wszystkich orzeczeń przywołanych przez SN warto przyjrzeć się zwłaszcza uzasadnieniu uchwały z dnia 20 lutego 1967 roku $^{20}$. Zasadnicza teza zawarta w tej uchwale sprowadzała się do stwierdzenia, że

16 Zob. przypis 5.

17 Tak B. Janiszewska, Glosa do wyroku SN z 30.05. 2000 r., IV CKN 898/00, „Przegląd Sądowy" 2002, nr 1.

18 Tak między innymi SN w wyroku z dnia 21 czerwca 1965 roku, III PR 18/65, „Nowe Prawo" 1966, nr 4.

19 M. Giaro, op. cit., s. 119 n.

20 Tylko bowiem w tym przypadku SN uargumentował swoje stanowisko. 
do wykonania prawa pierwokupu przysługującego Skarbowi Państwa z mocy art. 30 ustawy z dnia 14 lipca 1961 roku o gospodarce terenami w miastach i osiedlach [...] wystarczy zawiadomienie zbywcy nieruchomości przed upływem terminu określonego w art. 32 tej ustawy o złożeniu w formie aktu notarialnego odpowiedniego oświadczenia przez prezydium właściwej rady narodowej.

Sytuację tę SN potraktował jednak jako wyjątek od zasady, zgodnie z którą „W wypadku, gdy oświadczenie woli ma być złożone w odpowiedniej formie, powinno ono dojść do osoby, do której jest skierowane, w takiej właśnie postaci”. Przedstawione w uchwale argumenty stanowią wartościowy materiał do analizy problemu sposobu złożenia oświadczenia Banku o przedłużeniu okresu gwarancji bankowej.

W pierwszej kolejności zwraca uwagę zdanie, że wobec braku przepisu, który rozstrzygałby wprost o sposobie zawiadomienia zbywcy nieruchomości o złożeniu oświadczenia o wykonaniu prawa pierwokupu, odpowiedzi na to pytanie należy poszukiwać w całokształcie przepisów o składaniu oświadczeń woli oraz w przepisach specjalnie poświęconych wykonaniu prawa pierwokupu. Oznacza to, że pogląd wyrażony w tej uchwale nie ma charakteru uniwersalnego, ale powinien być każdorazowo weryfikowany w odniesieniu do konkretnej czynności prawnej. Zdanie to zachowuje swoją aktualność. W przypadku wyroku SN z dnia 21 sierpnia 2019 roku zabrakło jednak analizy zarówno w obszarze przepisów o składaniu oświadczeń woli, jak i przepisów o dokonywaniu czynności bankowych. SN nie dostrzegł zwłaszcza zmiany uwarunkowań prawnych polegającej choćby na wprowadzeniu w art. $77^{3} \mathrm{KC}$ pojęcia dokumentu i objęcia nim kopii. Ponadto SN dość lakonicznie odniósł się do regulacji wynikającej z Prawa bankowego, poprzestając jedynie na przywołaniu art. 81 ust. 2.

W uchwale z 27 lutego 1967 roku SN przedstawił dwa podstawowe argumenty świadczące o tym, że forma wymagana dla oświadczenia woli powinna również być formą, w jakiej adresat oświadczenia zostanie o nim powiadomiony. Pierwszy argument odwołuje się do konstrukcji oświadczenia woli. Zdaniem SN

do elementów takiego oświadczenia woli, bez których nie mogłoby ono powstać albo nie byłoby prawnie skuteczne, należą: sam akt woli, to znaczy podjęcie odpowiedniej decyzji przez osobę, która ma złożyć oświadczenie woli, wyrażenie woli na zewnątrz, zachowanie przy tej czynności odpowiedniej formy, jeżeli ustawa lub umowa stron tego wymaga, wreszcie dojście tego oświadczenia do adresata.

Tym samym SN dokonał tu wprawdzie odróżnienia pomiędzy faktem uzewnętrznienia woli wywołania skutków prawnych a faktem złożenia tego oświadczenia innej osobie, jednak uznał, że co do zasady wszystkie te elementy powinny tworzyć jedną całość. Ten wątek budzi kilka refleksji.

$\mathrm{W}$ procesie składania oświadczenia innej osobie etap uzewnętrznienia woli wywołania skutku prawnego, polegający na jej wyrażeniu w postaci pisma, nie jest czynnością pozbawioną jakiegokolwiek znaczenia prawnego. Jeśli decyzja podmiotu została podjęta w rzeczywistym zamiarze wywołania określonego skutku 
w sferze stosunków cywilnoprawnych, to jej wyrażenie powoduje dla tego podmiotu stan pewnego rodzaju związania. Nie ma on rzecz jasna charakteru definitywnego, ponieważ oświadczenie woli może być odwołane. Jednak skuteczność odwołania jest — zgodnie z art. $61 \S 1$ zd. $2 \mathrm{KC}$ — obwarowana w dwojaki sposób: wymaga zakomunikowania odwołania oświadczenia woli konkretnej osobie, czyli adresatowi oświadczenia woli, oraz konieczne jest, aby oświadczenie o odwołaniu doszło do adresata oświadczenia woli jednocześnie z tym oświadczeniem lub wcześniej. Można by z tego wyprowadzić wniosek, że złożenie oświadczenia woli jest czynnością ważną już z chwilą uzewnętrznienia woli w przepisanej formie ${ }^{21}$, chociaż — jeśli chodzi o oświadczenie, które ma być złożone innej osobie — skutki wywołuje dopiero $\mathrm{z}$ chwilą, w jakiej osoba ta mogła zapoznać się z jego treścią. Jeśli wobec tego składający oświadczenie woli podejmie działania ukierunkowane na powiadomienie adresata o jego treści, zwłaszcza jeśli wyśle list z pismem obejmującym oświadczenie lub za pośrednictwem poczty elektronicznej przekaże skan takiego pisma, to jedynym sposobem unicestwienia skuteczności oświadczenia jest jego odwołanie przy zachowaniu przesłanek wynikających z art. $61 \S 1$ zd. $2 \mathrm{KC}$. W okolicznościach analizowanego stanu faktycznego bezspornym jest, że Bank na zlecenie złożył oświadczenie o przedłużeniu okresu gwarancji. Poza zakresem analizy SN znalazło się natomiast to, jakie skutki wywołało to oświadczenie, a w szczególności czy miało ono charakter definitywny: czy było podjęte w zamiarze wywołania skutków prawnych, czy jedynie stanowiło swoisty projekt oświadczenia woli. Okoliczności zdają się wykluczać tę drugą ewentualność. Oryginał oświadczenia nie opuścił wprawdzie siedziby Banku, jednak z uwagi na zeskanowanie oświadczenia i przekazanie go w tej postaci Zleceniodawcy w celu poinformowania beneficjenta Bank musiał się liczyć z tym, że jego treść zostanie przedstawiona beneficjentowi gwarancji.

Pogląd SN, pośrednio wynikający z uzasadnienia glosowanego wyroku, zgodnie z którym oświadczenie Banku nie wywołało żadnych skutków prawnych, zdaje się podważać uznaną $\mathrm{w}$ doktrynie doniosłość aktu przejawu woli w formie pisemnej. Powszechnie bowiem zwraca się uwagę na to, że złożenie własnoręcznego podpisu realizuje między innymi funkcję akceptacyjną, polegającą na ostatecznym potwierdzeniu zamiaru wywołania skutku prawnego. W tym kontekście brak odniesienia się przez SN do odrębności stadium złożenia oświadczenia woli w przepisanej formie i stadium doręczenia oświadczenia jego adresatowi stanowi jego istotną lukę. SN nie rozważył między innymi, czy można utożsamiać funkcję formy czynności prawnej z funkcją „doręczenia” oświadczenia woli adresatowi. $\mathrm{W}$ przekonaniu autorki glosy nie jest to zabieg uprawniony. W tym drugim wypadku chodzi przede wszystkim o realizację funkcji komunikacyjnej, która polega na wywołaniu u adresata pewności, że oświadczenie woli o określonej treści zostało

${ }^{21}$ Zwłaszcza że w momencie złożenia oświadczenia woli ocenia się również dochowanie przez składającego wymaganej formy szczególnej. 
złożone. Można rozważyć, czy w sytuacji, kiedy dla złożenia oświadczenia wymagana jest forma szczególna, konieczne jest zapewnienie adresata o jej dochowaniu. Wydaje się, że odpowiedź na to pytanie powinna być twierdząca, jednak osiągnięcie tego celu niekoniecznie musi się wiązać z doręczeniem adresatowi oryginału pisma zawierającego oświadczenie woli.

Potrzeba zapewnienia bezpieczeństwa obrotu jako podstawowy argument wskazany w uchwale SN z 27 lutego 1967 roku za tym, że dojście do adresata oświadczenia woli powinno nastąpić w formie przewidzianej dla jego złożenia, nie może być absolutyzowana. W każdym razie należałoby oczekiwać od sądów rozpatrujących dany przypadek określenia, jakie konkretnie względy wynikające z konieczności zapewnienia bezpieczeństwa obrotu przemawiają za takim, a nie innym sposobem doręczenia adresatowi oświadczenia woli. Brak odniesienia się do tej kwestii w glosowanym wyroku nie pozwala na weryfikację oceny dokonanej przez SN. Jednocześnie okoliczności, jakie miały miejsce w tym stanie faktycznym, wywołują wrażenie, że działania banku-gwaranta podjęte wobec beneficjenta gwarancji nosiły znamiona nielojalności, naruszając tym samym stopień zaufania między tymi stronami. Skoro bowiem bank skorzystał z pośrednictwa zleceniodawcy celem przekazania treści swojego oświadczenia beneficjentowi jak zwykł był to czynić poprzednimi razy - musiał się liczyć z tym, że dojdzie ono do jego wiadomości. Samo zachowanie zleceniodawcy również wskazuje na intencjonalne manipulowanie kontrahentem-beneficjentem gwarancji za pomocą pisma banku o przedłużeniu okresu gwarancji. W tym stanie rzeczy powstała sytuacja, w której beneficjent gwarancji dowiedział się, że bank złożył oświadczenie o przedłużeniu gwarancji. Oświadczenie to nie zostało wobec beneficjenta odwołane. Wydaje się, że — właśnie ze względu na bezpieczeństwo obrotu — od podmiotu składającego oświadczenie woli należałoby oczekiwać, że działania, jakie podejmie w celu powiadomienia adresata o jego złożeniu, nie wprowadzą adresata w błąd ani co do faktu, ani co do treści oświadczenia. Skoro ustaloną między stronami normą było to, że oświadczenie banku w oryginale nie było od razu przesyłane beneficjentowi gwarancji, to mógł on pozostawać w uzasadnionym oczekiwaniu, że po zapoznaniu go $\mathrm{z}$ oświadczeniem $\mathrm{w}$ postaci skanu dotrze do niego również oryginał. Zaskakuje podniesiony w uzasadnieniu wyroku SN argument, że beneficjent jako profesjonalista posiadający fachową obsługę prawną powinien zdawać sobie sprawę z tego, że dopiero wraz z doręczeniem mu oryginału oświadczenia powstają jego skutki prawne. Status strony nie powinien mieć wpływu na obiektywną wykładnię art. $61 \mathrm{KC}$. Nie jest również jasny argument, że zwyczaj dotyczący składania oświadczeń woli między stronami nie może naruszać norm bezwzględnie obowiązujących, skoro art. $61 \mathrm{KC}$ traktuje się jako przepis o charakterze dyspozytywnym ${ }^{22}$.

22 P. Machnikowski, op. cit., s. 144. 
Zgodzić się trzeba ze zdaniem SN wyrażonym w uchwale z 20 lutego 1967 roku, że dojście do adresata oświadczenia woli powinno być zbieżne z tym, że nabierze on pewności „co do faktu złożenia oświadczenia i jego treści”. Nie sposób jednak nie zauważyć, że Sąd ten nie dokonał analizy doręczenia adresatowi kopii pisma zawierającego oświadczenie woli, zwracając jedynie uwagę na to, że niedopuszczalne byłoby na przykład telefoniczne powiadomienie o złożeniu oświadczenia na piśmie, które zatrzymała u siebie. Istotnie, samo powiadomienie drugiej strony o fakcie złożenia oświadczenia woli nie czyni zadość funkcji komunikacyjnej wynikającej z art. $61 \mathrm{KC}$. Jednak przesłanie kopii wiernie odzwierciedlającej oświadczenie woli ${ }^{23}$ skutkuje tym, że adresat oświadczenia zyskuje pełnoprawny dokument potwierdzający istnienie oryginału o tej samej treści. Na tej podstawie adresat w sposób niewątpliwy dowiaduje się o fakcie i treści złożonego oświadczenia. Trzeba też zauważyć, że nie w każdym przypadku posiadanie oryginału jest konieczne do realizacji uprawnień wynikających z dokonanej czynności prawnej24. Jeśli tak jest, adresat ma prawo żądać wydania mu oryginału oświadczenia, a w razie sporu między stronami - sąd może wystosować wezwanie do przedstawienia dokumentu stanowiącego dowód faktu istotnego dla rozstrzygnięcia sprawy $^{25}$. W niektórych sytuacjach powiadomienie adresata oświadczenia woli za pomocą kopii będzie środkiem bezpieczniejszym niż posłużenie się oryginałem. Próba doręczenia oryginału z pomocą różnego rodzaju posłańców niesie bowiem ze sobą ryzyko jego utraty lub próby sfałszowania. Zatem to składającemu oświadczenie woli należy pozostawić decyzję, czy przy powiadomieniu adresata wykorzysta oryginał czy kopię oświadczenia. Interes adresata oświadczenia woli w obu tych przypadkach wydaje się być w równym stopniu zabezpieczony.

Wreszcie należy również zwrócić uwagę na okoliczności, które zdaniem $\mathrm{SN}^{26}$ uzasadniają odstępstwo od zasady, że forma powiadomienia adresata powinna odpowiadać formie wymaganej do złożenia oświadczenia woli. Otóż zaliczone do nich zostały przede wszystkim: fakt złożenia oświadczenia woli przed notariuszem jako osobą zaufania publicznego oraz jednostronny charakter składanego oświadczenia woli, który wyłącza konieczność uzgadniania jego treści między stronami. Zwrócono również uwagę na to, że jednostronne oświadczenia woli zwykle mają charakter nieskomplikowany, co gwarantuje możliwość zapoznania się z nimi przy pomocy powiadomienia informującego adresata o istotnej treści oświadczenia. Tym samym raz jeszcze podkreślona została kluczowa, komunikacyjna funkcja doręczenia w rozumieniu art. $61 \mathrm{KC}$.

23 A więc na przykład w postaci kserokopii lub skanu oświadczenia.

${ }^{24} \mathrm{~W}$ przedmiotowej sprawie kwestia ta budzi pewne wątpliwości, jednak ze względu na zasadniczy przedmiot glosy i jej ramy nie ma miejsca na jej bliższą analizę.

25 Zob. art. 248 KPC.

${ }^{26}$ Cały czas chodzi tu o analizę stanowiska wyrażonego w uchwale SN z dnia 20 lutego 1967 roku, III CZP 88/66. 
Podsumowując tę część rozważań, należy wyrazić zdanie, że pogląd SN zawarty w przywołanej na wstępie tezie nie został w sposób przekonywujący uargumentowany, co w konsekwencji utrudnia jego weryfikację. Z kolei analiza motywów przywołanej w uzasadnieniu uchwały SN z dnia 20 lutego 1967 roku paradoksalnie zdaje się prowadzić do wniosków przeciwnych w stosunku do zdania wyrażonego przez SN w wyroku z dnia 21 sierpnia 2019 roku.

\section{WNIOSKI KOŃCOWE}

Wobec braku przepisu wyraźnie określającego sposób doręczenia oświadczenia woli adresatowi, za miarodajne należy uznać stanowisko, zgodnie z którym ocena sposobu doręczenia powinna być każdorazowo dokonywana w oparciu o całokształt przepisów o składaniu oświadczeń woli oraz przepisy regulujące konkretny rodzaj czynności prawnej.

Decydujące dla dokonania tej oceny jest kryterium funkcjonalne polegające na zapewnieniu adresatowi możliwości zapoznania się z oświadczeniem $\mathrm{w}$ taki sposób, aby nie było wątpliwości zarówno co do faktu złożenia, jak i jego treści.

Doręczenie kopii oświadczenia, w tym także przesłanie jego skanu, realizuje tak rozumianą funkcję komunikacyjną art. $61 \mathrm{KC}$, której podstawowym celem jest ochrona interesu adresata oświadczenia. Kopia nie stanowi zagrożenia bezpieczeństwa obrotu. Jest dokumentem w rozumieniu art. $77^{3} \mathrm{KC}$ i posiada określone znaczenie dowodowe.

Należy odróżnić fazę wyrażenia woli w przepisanej formie szczególnej od fazy jej zakomunikowania drugiej stronie. Skutki oświadczenia woli składanego innej osobie powstają wprawdzie dopiero z chwilą, gdy oświadczenie to doszło do niej w taki sposób, że mogła zapoznać się z jego treścią, jednak do tego momentu uzewnętrznienie aktu woli nie jest pozbawione doniosłości prawnej. Jeśli podmiot wyraża wolę wywołania skutków prawnych, to z chwilą podjęcia czynności zmierzających do zapoznania adresata $\mathrm{z}$ jego treścią powstaje po jego stronie swoisty stan związania. Potwierdza to określona w art. $61 \S 1 \mathrm{zd}$. $2 \mathrm{KC}$ reguła dotycząca możliwości odwołania oświadczenia woli.

Działania ukierunkowane na zaznajomienie adresata $\mathrm{z}$ treścią oświadczenia powinny być dokonywane przy zachowaniu lojalności kontraktowej, zwłaszcza zaś nie mogą one spowodować wprowadzenia adresata w błąd. 


\title{
COMMENTARY ON THE DECISION OF THE SUPREME COURT OF 21 AUGUST 2019, I CSK 349/18 - REMARKS ON THE NECESSITY OF DELIVERING THE DECLARATION OF WILL TO THE ADDRESSEE IN THE REQUIRED SPECIFIC FORM
}

\begin{abstract}
Summary
The subject of the gloss is the judgment of the Supreme Court of 21 August 2019, I CSK 349/18, in which the opinion was expressed that "if, under pain of invalidity, a specific declaration of the will made to another person is required to be made in a specific written form, then in order to assume that it has been made and has produced legal effects, it is necessary to deliver to the addressee the original of the letter containing the declaration of will". Despite the fact that this sentence is in line with the position prevailing both in the jurisdiction and in the literature, the author of the gloss draws attention to the need to verify the arguments that led to its formation. For this purpose the author analyses the motives indicated in the justification of the judgment, including the position of the Supreme Court cited in its resolution of 20 February 1967, III CZP 88/66. Finally, she comes to the conclusion that the categorical nature of the thesis referred to in the appendix is unjustified. This is supported not only by the lack of a specific provision resulting in an obligation to deliver a declaration of will to the addressee in the form required for its submission under pain of invalidity, but also by the functional interpretation of the provisions on submitting declarations of will. The author points out that a copy of the letter containing the declaration of will fully secures the interest of the addressee, which is expressed in the possibility to become fully acquainted with the fact of making the declaration and its content.
\end{abstract}

Keywords: written form, document, copy, original document, the delivering of the will declaration to another person, specific form

\section{BIBLIOGRAFIA}

Giaro M., Glosa do wyroku SN z dnia 26.08.2009 r., I CSK 32/09, „Państwo i Prawo” 2011, nr 1. Górska K., Pojęcie dokumentu w prawie cywilnym - glos $w$ dyskusji nad istota regulacji art. $77^{3}$ k.c., „Przegląd Ustawodawstwa Gospodarczego” 2021, nr 5.

Grykiel J., Uwagi do art. 61 k.c., Nb 35, [w:] Kodeks cywilny, t. 1. Komentarz do art. 1-352, red. M. Gutowski, Warszawa 2018.

Janiszewska B., Glosa do wyroku SN z 30.05.2000 r., IV CKN 898/00, „Przegląd Sądowy”2002, nr 1. Machnikowski P., [w:] Kodeks cywilny. Komentarz, red. E. Gniewek i P. Machnikowski, Warszawa 2019.

Mularski K., Radwański Z., [w:] System Prawa Prywatnego, t. 2, Prawo cywilne - część ogólna, red. A. Olejniczak, Z. Radwański, Warszawa 2019.

Piekarski M., Glosa do wyroku SN z dnia 21.06.1965 r., III PR 18/65, „Nowe Prawo” 1966, nr 4.

Safjan M., Uwagi do art. 61 k.c., Nb 10, [w:] Kodeks cywilny, t. 1. Komentarz. Art. 1-44910, red. K. Pietrzykowski, Warszawa 2020.

Słomko M., Złożenie oświadczenia woli w formie aktu notarialnego, „Przegląd Sądowy” 2005, nr 3. Sobolewski P., [w:] Kodeks cywilny. Komentarz, red. K. Osajda, Warszawa 2021. 